\title{
Stable disease after high dose interleukin-2 (HD IL-2) immunotherapy: observations on long term survival and clinical benefit of additional HD IL-2
} \author{
David McDermott ${ }^{7}$ \\ From Society for Immunotherapy of Cancer 29th Annual Meeting \\ National Harbor, MD, USA. 6-9 November 2014
}

Howard L Kaufman ${ }^{1}$, Sandra Aung ${ }^{2 *}$, Michael Morse ${ }^{3}$, Michael Wong $^{4}$, James Lowder ${ }^{5}$, Gregory Daniels ${ }^{6}$,

Patients with stable disease (SD) following cancer treatment have traditionally not been considered responders. We, and others, have previously shown that SD is an important response criteria in cancer patients treated with HD IL-2 immunotherapy [1-5]. Here we summarize findings from 13 sites, including $97 \mathrm{mRCC}$ and $170 \mathrm{mM}$ patients enrolled in the retrospective cohort of a national HD IL-2 database (www.proclaimregistry.com). Patients in the database were enrolled between 2006-2011, in an era of immune checkpoint inhibitors and targeted therapies. In metastatic renal cell carcinoma (mRCC) the median overall survival (mOS) was not reached in patients assessed to have SD post HD IL-2 (Figure 1). The mOS was over 2.5 years in patients with stable disease with metastatic melanoma (mM). The median follow-up for both diseases was 3 years. We further sought to examine whether patients with SD after 1 course, received benefit with additional HD IL-2 treatment. In mRCC patients that did not respond to treatment but continued onto another cycle of HD IL-2, the mOS was not reached and was statistically significant from patients that stopped treatment $(\mathrm{p}=0.0269)$ (Figure 2).

\section{Discussion}

Unlike chemotherapy and targeted therapies, immunotherapeutics have the unique potential to achieve long lasting durable responses in cancer. The continual homeostasis between the immune system and the tumor requires constant immune pressure, and tipping the balance toward the immune system using immunotherapy may be important. Registries such as PROCLAIM ${ }^{\text {SM }}$ provide data which may

${ }^{2}$ Prometheus Laboratory, San Diego, CA, USA

Full list of author information is available at the end of the article
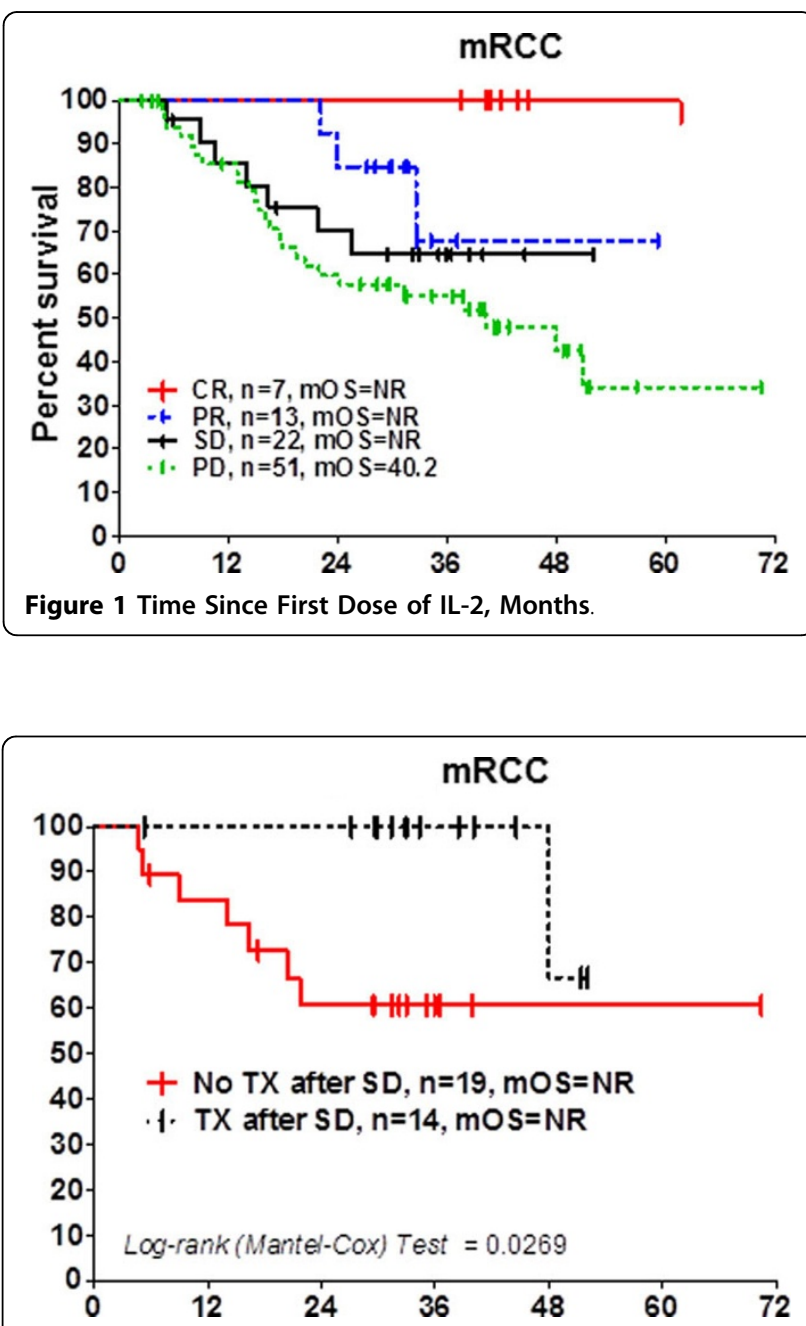

Figure 2 Time Since First Dose of IL-2, Months 
guide the optimal sequencing of therapies and/or prioritization of randomized clinical trials [6].

\title{
Conclusion
}

We conclude that stable disease is durable and should be considered a valuable end point. Consolidation of this response with additional HD IL-2 treatment following SD may be important.

\author{
Authors' details \\ ${ }^{1}$ Rutgers Cancer Institute of New Jersey, New Brunswick, NJ, USA. \\ ${ }^{2}$ Prometheus Laboratory, San Diego, CA, USA. ${ }^{3}$ Duke University, Durham, NC, \\ USA. ${ }^{4}$ Department of Medicine, University of Southern California, Los \\ Angeles, CA, USA. ${ }^{5}$ Prometheus Laboratory, San Diego, CA, USA. ${ }^{6}$ Moores \\ Cancer Center, San Diego, CA, USA. ${ }^{7}$ Beth Israel Hospital Deaconess Medical \\ Center, Boston, MA, USA.
}

Published: 6 November 2014

\section{References}

1. Payne R, Glenn L, Hoen H, Richards B, Smith JW, Lufkin R, Crocenzi TS, Urba WJ, Curti BD: Durable responses and reversibile toxicity of high-dose interleukin 2 treatment of melanoma and renal cancer in a community hospital biotherapy program. 2014, 2:13, doi:10.1186/2051-1426-2-13.

2. Merriman J, et al: Correlation of stable disease (SD) as best response with survival outcomes in patients (pts) with clear cell (cc) metastatic renal cell carcinoma (mRCC) treated with high-dose interleukin-2 (HD IL-2). ASCO 2014. J Clin Oncol 2014, 32:5s, (suppl; abstr 4577).

3. Morse $\mathrm{M}$, et al: High-dose (HD) IL-2 for metastatic renal cell carcinoma (mRCC) in the targeted therapy era: Extension of OS benefits beyond complete response (CR) and partial response (PR). ASCO 2014. J Clin Oncol 2014, 32:5s, (suppl; abstr 4523).

4. Daniels $G$, et al: Improved median overall survival (OS) in patients with metastatic melanoma $(\mathrm{mM})$ treated with high-dose (HD) IL-2: Analysis of the PROCLAIM 2007-2012 national registry. ASCO 2014. J Clin Oncol 2014, 32:5s, (suppl; abstr 9054).

5. Hughes T, lodice G, Basu S, Fung H, Maciejewski J, Nathan S, Rich E, Bines S, Kaufman H: Clinical Benefit of High Dose IL-2 (HD IL-2) Therapy Depends on the Kinetics of Response: Evidence for Improved Overall Survival in Patients with Stable Disease., (submitted to Cancer Immunology Immunotherapy).

6. Kaufman HL, Wong KK, Daniels GA, McDermott DF, Aung S, Lowder JN, Morse MA: The Use of Registries to Improve Cancer Treatment: A National Database for Patients Treated with Interleukin-2 (IL-2). Journal of Personalized Medicine 2014, 4:52-64.

doi:10.1186/2051-1426-2-S3-P88

Cite this article as: Kaufman et al:: Stable disease after high dose interleukin-2 (HD IL-2) immunotherapy: observations on long term survival and clinical benefit of additional HD IL-2. Journal for

ImmunoTherapy of Cancer 2014 2(Suppl 3):P88.

\section{Submit your next manuscript to BioMed Central and take full advantage of:}

- Convenient online submission

- Thorough peer review

- No space constraints or color figure charges

- Immediate publication on acceptance

- Inclusion in PubMed, CAS, Scopus and Google Scholar

- Research which is freely available for redistribution

Submit your manuscript at www.biomedcentral.com/submit
C Biomed Central 